Poznańskie Studia Teologiczne 27(2013), s. 211-230.

Jarosław Moskałyk

Uniwersytet im. Adama Mickiewicza w Poznaniu

Wydział Teologiczny

\title{
Doświadczenie historyczno-religijnej alienacji a współczesne relacje wewnątrz chrześcijaństwa
}

Zjawisko historycznego wyobcowania $\mathrm{w}$ chrześcijaństwie stanowi jedno z najbardziej złożonych i zarazem dramatycznych doświadczeń w jego realizacji. Utworzone i z istoty swej przeznaczone do działania w jedności i dla jedności wielu w ściśle określonym celu, niestety, stopniowo przestaje pełnić tę funkcję, a właściwie szczególną misję wobec człowieka i świata w ich perspektywie zbawczej. Głównym powodem zniekształcenia idei chrześcijańskiej w dziejach ludzkości jest oczywiście sam człowiek, a dokładniej mówiąc, jego brak wierności i rezygnacja ze służby takim wartościom, jak jedność i niepodzielność, stanowiącym pochodną przynależności chrześcijańskiej. Jest to niewątpliwie konsekwencja postrzegania chrześcijaństwa w kategoriach przestrzeni nieograniczonej swobody oddziaływania człowieka oraz jego dążności do zarządzania nim. Jak można było oczekiwać, z czasem owa tendencja zaczęła przybierać coraz poważniejsze i tym samym niebezpieczne rozmiary. Chodziło tu nie tylko o nadużycia związane z niezachowaniem przez chrześcijan tego, co chrześcijańskie, ale także o coraz większe rozbicie wspólnoty chrześcijańskiej spowodowane sporami o tzw. prawowierność i nadrzędność wyznaniową. W wyniku tego musiało dojść do ostrej konfrontacji ideowo-społecznej i jednocześnie wyobcowania w wierze poszczególnych wspólnot religijnych. Naturalnie za głównego winowajcę podziału chrześcijan uznawano zawsze stronę przeciwna, natomiast możliwość zmiany tego stanu widziano jedynie przez powrót do ,jednej owczarni”, której przewodzić może strona przekonana o doskonałości swego Kościoła ${ }^{1}$. Oznaczało to konieczność uznania doktryny, zasad kultycznych i prawnych obowiązujących po stronie tylko jednej opcji wspólnotowej i podporządkowanie się im.

Twarde stanowisko oraz bezkompromisowa obrona swoich racji nie sprzyjały łagodzeniu napięcia ani też nie mogły wpłynąć na zahamowanie procesu wyobcowania w łonie chrześcijaństwa. Wręcz przeciwnie, skutkowało to kolejnymi podzia-

\footnotetext{
${ }^{1}$ Por. F. Biot, Von der Polemik zum Dialog. Steine auf dem Weg zur Einheit der Christen, Wien 1966, s. 34-47; N. Nissiotis, Ökumenische Bewegung und Zweites Vatikanische Konzil, „Kerygma und Dogma“ 11 (1965), nr 3, s. 208-219.
} 
łami i rozczłonkowaniem jednej wspólnoty. Ostatecznie osiagnnięto punkt krytyczny, ponieważ nastąpiło niemal zupełne wyczerpanie środków konfrontacyjnych i jednocześnie uświadomiono sobie, że bezsensowne jest trwanie chrześcijan w warunkach całkowitej izolacji. Wymusiło to też niejako nowe spojrzenie na pespektywę zjednoczenia. Paradoksalnie więc osiagnięcie absurdalnego poziomu wzajemnego oddalenia się chrześcijan i wraz z tym poczucie ogromnej bezradności doprowadziło do samokrytycznej refleksji i zmiany postawy. W związku z tym przedmiotem poniższych rozważań będą przemiany myślenia i otwarcie Kościoła katolickiego na inne wyznania chrześcijańskie oraz ożywienie relacji w całym środowisku chrześcijańskim i opracowanie nowej formy komunikacji chrześcijan z innymi wspólnotami religijnymi, jakie dokonało się w ostatnim półwieczu.

\section{Próba zmiany modelu relacji}

Przez długi okres działalności Kościoła katolickiego, a praktycznie od schizmy (XI w.) do II Soboru Watykańskiego, dominowało w nim niemal niezmienne przekonanie o własnej doskonałości (perfecta Ecclesiae). Nietrudno sobie wyobrazić, co tego rodzaju postawa mogła oznaczać dla innych wspólnot chrześcijańskich i w końcu dla niego samego. Przede wszystkim wprowadziła atmosferę niezwykłego zdystansowania, pogardy, nieufności i znaczącej ignorancji w stosunku do pozostałych wyznań. Dziś przeważająca większość ekumenistów nie ma wątpliwości, że w przeszłości u podstaw utrwalonej niechęci Kościoła katolickiego do tzw. innowierców stały eklezjologiczny tryumfalizm i jurydyczny konserwatyzm ${ }^{2}$. To przede wszystkim one powodowały, że ta wspólnota religijna sama wyznaczyła granice prawowierności i wiarygodności Kościoła Chrystusowego, zacieśniając je właściwie do Kościoła rzymskiego, a równocześnie odmawiając tego miana innym Kościołom, nierzadko także odmawiając im przymiotu eklezjalności. Efektem takiego nastawienia rzymskiego katolicyzmu wobec pozostałych wspólnot chrześcijańskich był ich zdecydowany opór i negacja sposobu postrzegania Kościoła przez Rzym. Wskutek tego w całym Kościele chrześcijańskim powstały dwa pod wieloma względami zróżnicowane fronty, wzajemnie się zwalczające i - co za tym idzie - się wykluczające. Po obu stronach brakowało odwagi i stanowczości potrzebnych do przerwania zaklętego koła wzajemnej nieufności i podejrzliwości. Brakowało też siły woli i determinacji, by przynajmniej częściowo ustąpić z zajmowanego stanowiska doktrynalnego i zrezygnować z postawy konfrontacyjnej.

\footnotetext{
${ }^{2}$ Por. R. Slenczka, Die dogmatische Relevanz der Ergebnisse theologischer Gespräche zwischen römisch-katholischen und evengelischen Theologen, „Ökumenische Rundschau“ 29 (1980), H. 4, s. 440-460.
} 
Dopiero na II Soborze Watykańskim podjęto poważny namysł nad wizją eklezjologiczną i zjawiskiem wyobcowania w Kościele Chrystusowym ${ }^{3}$. Niemniej jednak trzeba obiektywnie stwierdzić, że do tej ważnej zmiany orientacji w Kościele katolickim nie doszło przypadkowo czy wyłącznie za pośrednictwem jakiejś siły odśrodkowej. Złożyło się na to kilka wyróżniających się czynników, które spowodowały ostateczny przełom i pozytywną reakcję na problem zamknięcia na dialog.

\section{Inicjatywy zewnętrzne}

Za cechę charakterystyczną należy uznać to, że pierwsze impulsy w sprawie rewizji postawy otwartości i współpracy chrześcijan pochodziły z kręów ewangelickiego i prawosławnego. W roku 1910 z inicjatywy ewangelików została zorganizowana konferencja misyjna z wyraźnie zaznaczoną formułą ekumeniczną w Edynburgu. To przedsięwzięcie zbliżeniowe miało być próbą przełamania bariery wzajemnego dystansu, wrogości, lęku i niepewności, ale także miało służyć przerwaniu rywalizacji między wyznaniami chrześcijańskimi. Praktycznym wyrazem wskazanej inicjatywy jest działalność organizacji „Życie i Działanie” z 1918 roku, a następnie powołanie w 1920 roku do istnienia komisji doktrynalnej „Wiara i Ustrój”. Skutkiem intensyfikacji podejmowanych przez ewangelików wysiłków mających doprowadzić do zbliżenia było utworzenie w 1948 roku w Amsterdamie Światowej Rady Kościołów, która nie stanowi organizacji nastawionej na ogarnięcie swoim zasięgiem jak największej liczby podmiotów eklezjalnych i wspólnotowych ani nie ma za zadanie ścisłego egzekwowania postępu zjednoczeniowego chrześcijan ${ }^{4}$. Jej celem jest tworzenie jednej społeczności wierzących, która zajmować się będzie niwelowaniem wzajemnego dystansu w realizacji swej misji chrześcijańskiej.

Wcześniej jeszcze, bo już na początku XX wieku, pojawiły się istotne sygnały wzywające do odnowy jedności wśród chrześcijan, których zwolennikiem było środowisko prawosławne ${ }^{5}$. Intencją honorowego zwierzchnika prawosławia w świecie patriarchy Joachima III było przede wszystkim zainicjowanie ruchu

\footnotetext{
${ }^{3}$ Rzeczywistość tę potwierdzają dokumenty soborowe: Konstytucja dogmatyczna o objawieniu Bożym Dei Verbum, Konstytucja dogmatyczna o Kościele Lumen gentium, Dekret o ekumenizmie Unitatis redintegratio, jak również Dekret o Kościołach wschodnich katolickich Orientalium Ecclesiarum. Zob. K. Karski, Dażenia ekumeniczne we współczesnym świecie, Warszawa $1986{ }^{2}$.

${ }^{4}$ Zgodnie z postanowieniem doktrynalnym z New Delhi z 1961 roku odnośnie do Światowej Rady Kościołów jest to społeczność Kościołów, które wyznają że Pan Jezus Chrystus jest Bogiem i Zbawicielem, i dlatego dążą wspólnie do wypełnienia tego, do czego są powołane ku chwale Boga Ojca, Syna i Ducha Świętego. Zob. L. Górka, S.C. Napiórkowski, Kościoły czy Kościót. Wybrane zagadnienia z ekumenizmu, Warszawa 1995, s. 47.

${ }^{5}$ Tamże, s. 47. Chodzi tutaj o znamienny przykład otwartości wobec idei zjednoczeniowej w Kościele chrześcijańskim, wyrażonej w Orędziu do wszystkich siostrzanych Kościołów prawoslawnych patriarchy ekumenicznego Joachima III z 1904 roku.
} 
zjednoczeniowego wewnątrz całego Kościoła prawosławnego. W złagodzeniu napięcia oraz umocnieniu relacji między wspólnotami prawosławnymi hierarcha widział wówczas szansę na nawiązanie także bliższych więzi partnerskich ze stroną rzymskokatolicką oraz protestancką.

Choć pierwsze próby zwierzchnika prawosławnego dotyczące odnowienia komunii w prawosławiu oraz całej rodzinie chrześcijańskiej były raczej pewnego rodzaju sondażem w kwestii reakcji na potrzebę nawiązania wzajemnych relacji między wspólnotami chrześcijańskimi, to jednak ich skutkiem było ważne poruszenie sumień i obudzenie intencji zjednoczeniowej. Za kolejny krok w propagowaniu skutecznej formy działań ekumenicznych ze strony prawosławia należy uznać wydanie w 1920 roku Orędzia patriarchatu ekumenicznego, gdzie znajduje się propozycja utworzenia ,jednej wspólnoty eklezjalnej” i podjęcia wyzwania ścisłej współpracy na rzecz jedności adresowana do wszystkich Kościołów chrześcijańskich ${ }^{6}$. Dziś ten odważny gest prawosławnych wielu badaczy uznaje za głęboko przemyślany i uzasadniony akt, mający najpierw doprowadzić do zapanowania nad historycznymi uprzedzeniami, a potem do pokonania pozadoktrynalnych różnic. On też był później podstawą przyszłej organizacji Światowej Rady Kościołów, natomiast, jak wpłynął na sposób postrzegania przyszłości ruchu ekumenicznego przez katolików, trudno aktualnie jednoznacznie określić. Niemniej jednak, co wydaje się niezwykle ważne, odtąd zupełnie zmieniło się podejście chrześcijan do zagadnienia podziału i wzajemnego wyobcowania. Zmieniła się również świadomość katolików odnośnie do chrześcijaństwa rozumianego jako istnienie wielu podmiotów, które mogą wzajemnie na siebie oddziaływać. W końcu uznano metodę dialogu partnerskiego za niezastapione narzędzie w procesie wzajemnego zbliżenia. Tylko dzięki prawdziwej akceptacji funkcji dialogu może się dokonywać zmiana postawy ludzkiej oraz odnowa struktur kościelnych. Ostateczne przełamanie w Kościele katolickim dawnych oporów i niechęci dotyczących partnerskich relacji wewnątrz chrześcijaństwa odbyło się po jego rezygnacji ze środków konfrontacyjnych w komunikacji międzywyznaniowej oraz po odstapieniu od metody unionistycznej jako czynnika warunkującego możliwość dialogu. Wszakże zasadnicza zmiana w postawie katolików była spowodowana II Soborem Watykańskim.

\section{Dążenie do jedności na zasadzie partnerskiej}

Aby przed 50 laty w Kościele katolickim można było dojść do przekonania o znaczeniu spotkania i o sensie debaty z tzw. innowiercami, trzeba było pokonać wielowiekowy stereotyp o mniejszej wartości oraz przekonanie o względności duchowo-zbawczych doktryn innych chrześcijan. Do utrwalenia tego stereotypu niegdyś w dużej mierze przyczynili się sami papieże, którzy w swoich

\footnotetext{
${ }^{6}$ Por. S.C. Napiórkowski, Historia ruchu ekumenicznego, Lublin 1972, s. 11-26.
} 
oficjalnych wystąpieniach najczęściej utożsamiali Kościół Chrystusowy z Kościołem katolickim, którego najwyższym reprezentantem jest biskup Rzymu? Tego rodzaju stanowisko poszczególnych zwierzchników na Stolicy Piotrowej było pewną zasadą i wzorem do naśladowania w całym Kościele łacińskim, a także przykładem przypisywania jedynie temu Kościołowi cech powszechności, nienaruszonej pełni i jedności. W konsekwencji przeświadczenie owo sprzyjało kształtowaniu postawy dystansu i pasywności papieży wobec problemu podziału chrześcijan oraz ewentualnych prób ich zjednoczenia. Jeśli wówczas pojawiały się jakieś sugestie programowe mające na celu pojednanie wewnątrz chrześcijaństwa, to były one zawsze oparte na jednej i tej samej wizji oraz zmierzały do podporządkowania „akatolików” Kościołowi rzymskiemu.

Wskazywanie na doskonałość struktury Kościoła katolickiego i jego przewagę w dziele uświęcania swoich członków było formą nacisku na „odłączonych chrześcijan" i miało ich skłonić do rewizji swojej sytuacji duchowej oraz do powrotu na łono prawdziwego Kościoła. W każdym bądź razie takie nastawienie doktrynalne wobec „odłączonych” coraz bardziej uwidoczniało się od I Soboru Watykańskiego i podyktowane było pragnieniem odizolowania wiary katolickiej. Jednakże tendencja do izolacji albo do zapewnienia wszechwładności katolicyzmu przynajmniej w postawie niektórych papieży (Leona XIII, Benedykta XV, Piusa XI, Jana XXIII) okresu między dwoma Soborami Watykańskimi przenikała się ze świadomością niegodziwości stanu rozdziału chrześcijaństwa i pewnymi oznakami dążenia do naprawienia zaistniałej sytuacji ${ }^{8}$. Dokonywała się również symboliczna przemiana w formule dotychczasowej percepcji chrześcijan wyznania nierzymskokatolickiego, mianowicie postanowiono zrezygnować z określania ich jako: „schizmatyków”, „,heretyków”, „odszczepieńców” itd9. Bardzo ważne były katolickie inicjatywy ekumeniczne podejmowane podczas słynnych kongresów velehradzkich (1907-1936) ${ }^{10}$. Wówczas to w wyniku światłego rozpoznania idei pojednania oraz nawiązania do odrodzeniowych XIX-wiecznych nurtów oświatowo-religijnych w Czechach i na Słowacji duchowni i teologowie morawscy dali znaczący impuls do nawiązania szczerych relacji w rodzinie chrześcijańskiej ${ }^{11}$.

${ }^{7}$ W. Hryniewicz, Wschód i Zachód chrześcijański: od schizmy do dialogu, w: Jan Paweł II $w$ dialogu miłości z Kościołem wschodnim, wybór i oprac. A. Polkowski, wstęp W. Hryniewicz, Warszawa 1984, s. 28-32.

${ }^{8}$ Por. Z. Zieliński, Papiestwo i papieże dwóch ostatnich wieków, Warszawa 1983, s. 277-538.

${ }^{9}$ L. Górka, S.C. Napiórkowski, Kościoły czy Kościót, s. 23.

${ }^{10}$ Por. F. Grivec, Memorabilia ex historia Conventuum Velehradensium, AAV12 (1932), s. 25-31; L. Górka, Doktryna ekumeniczna kongresów welehradzkich (1907-1936). Studium z zakresu historii katolickiej myśli ekumenicznej, w: Studia ekumeniczne, red. J. Myśków, t. 1, Warszawa 1982, s. 5-122; L. Górka, Dziedzictwo Ojców. Ekumeniczny charakter tradycji welehradzkiej, Warszawa 1995, s. 99-121.

${ }^{11}$ Grupa inicjująca Kongresy należała do Apostolatu świętych Cyryla i Metodego oraz była zaangażowana w publikację czasopisma „Slavorum Litterae Theologicae”. Zob. F. Cinek, Velehrad víry, Olomouc 1936, s. 443. 
Organizatorzy wspomnianych kongresów postawili przed sobą bardzo prosty i zarazem klarowny cel, umożliwić spotkanie świata katolickiego i prawosławnego Słowiańszczyzny i następnie pozwolić obydwu stronom podjąć rzeczowe rozmowy na temat tego, co je łączy oraz co utrudnia wzajemne relacje. Całe przedsięwzięcie okazało się niezwykle owocnym przykładem wymiany doświadczeń, zmniejszenia dystansu i zapoczątkowania realnej współpracy w sferze poszukiwania jedności chrześcijańskiej ${ }^{12}$. Optyka zjednoczeniowa zaprezentowana w Velehradzie powoli kreśliła nowy trend otwarcia i działania, który ostatecznie musiał powodować zmianę wzajemnych relacji katolików i prawosławnych. Później wymusiły ją również procesy historyczne oraz nowe wyzwania duchowe stawiane całemu chrześcijaństwu.

$\mathrm{Z}$ pewnością przełomowym momentem całego przedsięwzięcia velehradzkiego było także dokonanie swoistego rachunku sumienia w kwestii dawnego jednostronnego obciążania winą za rozbicie chrześcijaństwa. Teraz postanowiono uznać, że odpowiedzialność za istniejący podział ponoszą obie strony i one w jednakowy sposób są zobowiązane odmienić tę sytuację tak, aby chrześcijanie nie byli już więcej zgorszeniem dla świata. Poza tym przypomniano, że poszukiwanie niegdyś utraconej jedności chrześcijan musi się odbywać przy wykorzystaniu elementów łączących wspólnoty Wschodu i Zachodu w wymiarze eklezjologicznym. Najgłębszą podstawę wzajemnego porozumienia stanowić ma więź mistyczno-sakramentalna jako pierwiastek łączący obie tradycje w jedną całość niepodzielonego Ciała Chrystusa. Obecne zmierzanie ku pełnej jedności chrześcijan nie może w niczym ustępować wzorcowi wspólnoty ustanowionej przez Jezusa Chrystusa, która realizowana była w pierwotnym Kościele ${ }^{13}$.

Jeśli chodzi o praktyczne zastosowanie doktryny, metody i strategii zjednoczeniowej wypracowanej podczas kongresów w Velehradzie, to w przeciwieństwie do szeregu innych tego typu inicjatyw odegrała ona istotną rolę w kształtowaniu intuicji ekumenicznej współczesnego Kościoła. Rzeczywistym potwierdzeniem tego było mniej lub bardziej bezpośrednie odwołanie się do tamtego źródła myśli i intencji w dokumentach soborowych, w tym głównie w Dekrecie o ekumenizmie. Ponadto szczególną wagę miały wyrazy uznania dla owoców kongresów ze strony papieża Jana XXIII, który w swoim liście apostolskim Magnifici Eventus z 1963 roku odniósł się do idei velehradzkiego pojednania oraz określił ją jako ważny znak na drodze przyszłego zjednoczenia ${ }^{14}$. W podobnym tonie wypowiedział się również papież Paweł VI w liście apostolskim Antiquae nobilitatis z $1969 \mathrm{roku}^{15}$. Z kolei Jan Paweł II przypomniał o wyjątkowej żywotności dzieła velehradzkiego podczas swojej wizyty w Velehradzie w 1990 roku. Wów-

\footnotetext{
${ }^{12}$ Por. tamże, s. 620-627.

${ }^{13}$ Por. L. Górka, S.C. Napiórkowski, Kościoty czy Kościót, s. 38.

${ }^{14}$ Acta Apostolicae Sedis 55 (1963), s. 434-439.

${ }^{15}$ Acta Apostolicae Sedis 61 (1969), s. 137-149.
} 
czas to między innymi zauważył, że „kamień węgielny europejskiej jedności znajduje się także w Velehradzie"16. Europę w wymiarze religijnym kształtują dwie różniące się między sobą tradycje, lecz obie one do siebie należą. Wspólnie stanowią o dawnym, a także współczesnym chrześcijańskim dziedzictwie Europy $^{17}$. Dlatego aktualnie sprawa jedności chrześcijan przestała być przedmiotem dyskusji oraz działania wyłącznie niekatolików, ale jest także ważnym punktem zainteresowania strony katolickiej.

\section{Nowa forma działania zjednoczeniowego}

Do istotnego przełomu w sferze otwartości Kościoła Rzymskokatolickiego na ruch ekumeniczny - jak wcześniej w przypadku wspólnot niekatolickich doszło dzięki oddziaływaniu oddolnemu. Jednym z przykładów takiej inicjatywy jest założona w 1952 roku Katolicka Konferencja do Spraw Ekumenizmu (Katholische Konferenz für ökumenische Fragen) ${ }^{18}$. Znaczący wpływ na powstanie tej organizacji miało holenderskie środowisko katolickie, które w sposób szczególny zaangażowało się w próbę nawiązania łączności z protestanckim nurtem ekumenicznym. Do podstawowych zadań Konferencji należało: skupienie się na ważnych problemach, które przed wiekami doprowadziły do oddalenia wspólnot chrześcijańskich, obiektywna ocena skutków istniejącego podziału, rzeczowa analiza dotychczasowych przedsięwzięć zjednoczeniowych niekatolików oraz ustalenie kryteriów współpracy obowiązujących stronę katolicką podczas prób pojednania. Przyjęto również zasadę, że spotkania licznej grupy teologów - około 80 osób - stanowiących trzon organizacji, będą się odbywać rokrocznie w innym kraju Europy. Stąd nie bez powodu pojawiały się głosy, że Konferencja do spraw Ekumenizmu utworzyła podwaliny pod przyszły Sekretariat Jedności $(1960)^{19}$.

Sekretariat ten odegrał bardzo ważną rolę podczas II Soboru Watykańskiego, pełniąc funkcję Komisji Soborowej ${ }^{20}$. Dzięki wyposażeniu w odpowiednie instrumenty jednostka ta mogła w sposób bezpośredni wpływać na ekumeniczny wymiar dokumentów soborowych. Za jej pośrednictwem na obrady Soboru zaproszeni zostali także obserwatorzy spoza Kościoła katolickiego, co było znaczącym

${ }^{16}$ „L' Osservatore Romano” (Pol), 11 (1990), nr 5, s. 25.

${ }^{17}$ Tamże.

${ }^{18}$ J. Willebrands, Augustin Bea - Vorkämpfer für die Einheit der Christen, für die Religionsfreiheit und ein neues Verhältnis zum jüdischen Volk, w: D. Bader, S. Schmidt, Kardinal Augustin Bea. Die Hinawendung der Kirche zu Bibelwissenschaft und Ökumene, München - Zürich 1981, s. 34-35.

${ }^{19}$ Por. L. Górka, S.C. Napiórkowski, Kościoły czy Kościót, s. 45.

${ }^{20}$ Por. Acta et Documenta Concilio Oecumenico Vaticano II Apparando, Series I, Vol. I, Typis Polyglottis Vaticanis 1960. Sekretariat, występując w roli Komisji soborowej, przyczynił się do zredagowania trzech projektów: o ekumenizmie, o wolności religijnej oraz o relacji Kościoła do religii niechrześcijańskich. 
wyrazem otwarcia się na głos i wspólną obecność podczas powstawania dokumentów Soboru. Jednak na jeszcze większe uznanie zasługuje to, że uczynienie przez stronę katolicką tak wymownego gestu wobec innych Kościołów i wspólnot chrześcijańskich nie stało się tylko jednorazowym aktem dobrej woli. Zreszta, w przeciwnym razie, czy mógłby on świadczyć o szczerej intencji strony zapraszającej. Odtąd zaczęto wcielać ideę porozumienia i zbliżenia międzywyznaniowego według nowego kryterium wzajemnej akceptacji. To wszystko, co udało się wypracować podczas Soboru także przy aktywnym oddziaływaniu obserwatorów, obecnie może być kontynuowane i udoskonalane.

Nie zaniechano więc już idei organizowania oficjalnych wielostronnych spotkań, lecz jedynie rozwijano ją i umacniano. Natomiast zainicjowanie szerokiego programu wdrażania w życie zasad ekumenicznych z czasem doprowadziło do prawdziwej recepcji dialogu partnerskiego, gdzie katolicy w sposób szczególny zobowiązani są do włączania się $\mathrm{w}$ proces edukacji ekumenicznej swych wiernych, zarówno w wymiarze lokalnym, jak i powszechnym, co ma pogłębiać relacje i pojednanie z innymi chrześcijanami. Widać tu istotną przemianę względem dawnego sposobu postrzegania wspólnot niekatolickich, gotowość wnoszenia własnego wkładu w proces wzajemnego zbliżenia, sprzyjanie obecności strony niekatolickiej podczas spotkań katolickich, inicjowana jest także współpraca. To jest właśnie ten znaczący zwrot, który ma charakter nieodwracalny.

Dzięki temu niwelowanie skutków wzajemnej alienacji chrześcijan może nabrać całkiem realnego znaczenia. Nie sposób tu przecenić wpierw przeobrażenia, które się dokonało wewnątrz Kościoła Rzymskokatolickiego. Bez niego też trudno byłoby osiagnąć dotychczasowy postęp we wzajemnym zbliżeniu chrześcijan, dialog ekumeniczny niewątpliwie charakteryzowałby się dzisiaj zupełnie inną dynamiką i stopniem oddziaływania. W tym kontekście wystarczy wskazać tylko na niektóre akty ożywiające i wzmacniające aktywność katolików w ruchu ekumenicznym. Są nimi oprócz oczywiście Dekretu o ekumenizmie (Unitatis redintegratio), Konstytucji o Objawieniu Bożym (Dei Vervum), Konstytucji dogmatycznej o Kościele (Lumen gentium), Dekretu o Kościołach wschodnich katolickich (Orientalium Ecclesiarum), także: Dyrektorium ekumeniczne I (1967) i Dyrektorium ekumeniczne II (1970), Dokument roboczy w sprawie dialogu ekumenicznego (1970), Dokument roboczy o współpracy ekumenicznej na płaszczyźnie regionalnej, krajowej i diecezjalnej (1975), Instrukcja o dopuszczeniu do komunii świętej w Kościele katolickim chrześcijan innych wyznań (1972), Dokument studyjny o wspólnym świadectwie $(1980)^{21}$ itd.

Ponadto głębszego uzasadnienia współczesnej motywacji działania zjednoczeniowego w Kościele katolickim należy doszukiwać się w historycznej aktu-

${ }^{21} \mathrm{~W}$ marcu 1993 roku miało miejsce przyjęcie nowego Dyrektorium Ekumenicznego przez papieża Jana Pawła II. Tekst polski w „Communio” 14 (1994), nr 2, s. 3-93. 
alizacji naukowego nurtu personalistycznego. Rozwinięcie dziedziny personalistycznej na długo przed Soborem Watykańskim II $^{22}$ miało ogromny wpływ na soborowe ożywienie ekumeniczne. Zwolennicy współczesnej „rewolucji personalistycznej” doprowadzili do bardzo ważnego przełomu w sferze myślenia o człowieku w kategoriach autonomicznej indywidualności lub autonomicznego indywiduum. Dzięki temu jednostkę w większym stopniu zaczęto utożsamiać z zewnętrzną relacją osobową, społeczną, ogólnoludzką i relacjami z otaczającym światem. Na tej podstawie weryfikowano również zależności osoby od przemiany życia indywidualnego i społecznego oraz wrażliwości na problemy natury społecznej i religijnej. Nowego wymiaru nabrała tu teoria o współczesnej bardziej złożonej i integracyjnie utrudnionej sytuacji jednostki ludzkiej czy pojedynczych społeczeństw. Dlatego chociażby ze względu na obronę wartości duchowych $\mathrm{w}$ tym świecie katolicy powinni współpracować z prawosławnymi, protestantami oraz innymi wspólnotami chrześcijańskimi, jednocześnie nie zapominając o współpracy z religiami monoteistycznymi, pogańskimi czy ludźmi niewierzącymi.

Impuls dany przez twórców współczesnego personalizmu, niezależnie od pierwotnych założeń, bardzo mocno wniknął przede wszystkim w aktualną świadomość eklezjologiczną i zdynamizował relacje między Kościołami. Począwszy od Soboru Watykańskiego II, stał się bezsprzecznie czynnikiem pobudzającym współdziałanie podmiotów kościelnych i wspólnot zarówno na płaszczyźnie teoretycznej, jak i modlitewnej. Wreszcie dzięki odwołaniu do zasady personalizmu skuteczniej zaczęto wdrażać idee pojednania Kościołów Bożych. Dawną nietolerancję i wyobcowanie zastapiono priorytetem wolności i autonomii religijnej postrzeganym jako nieodzowny warunek dialogu ${ }^{23}$.

\section{Idea wzajemnego przenikania}

Już podczas Soboru Watykańskiego II zaczęły pojawiać się coraz liczniejsze głosy o zbyt ograniczonym polu wzajemnego oddziaływania na siebie chrześcijan z powodu m.in. braku należytej wiedzy o drugiej stronie, co jest także efektem długotrwałego wyobcowania. Nie może to ułatwiać dialogu, ale - wręcz przeciwnie - zdecydowanie go utrudnia. Dlatego między innymi zaproponowano lepszą organizację studiów, włącznie $\mathrm{z}$ utworzeniem specjalistycznych insty-

${ }^{22} \mathrm{Za}$ jednego ze znaczących inspiratorów współczesnego personalizmu indywidualistyczno-społecznego uznawany jest Immanuel Mounier (1905-1950). Był on założycielem czasopisma społeczno-politycznego „Esprit” (1932), które stało się równocześnie zaczynem ruchu intelektualnego pod nazwą Esprit. Idea fillozoficzno-teologiczna Mouniera dotycząca osoby i społeczności osób we współczesnym świecie, w szczególności wobec wyzwania humanizacji i odrodzenia, pozostaje wciąż niezwykle intrygująca.

${ }^{23}$ Por. L. Janssens, Wolnossć sumienia $i$ wolność religijna, Warszawa 1970, s. 27-29. 
tutów teologicznych oraz profilowanych kursów. Ponadto jako priorytetowy zaczęto traktować postulat, aby unikać sztucznego podziału Kościołów i wspólnot chrześcijańskich na Wschodzie i Zachodzie, gdyż to niejako wymusza dalszą izolację, a z pewnością nie sprzyja pogłębieniu rzetelnej wiedzy na temat różnic i odmienności między poszczególnymi podmiotami. Ponadto zwrócono uwagę na potrzebę uszanowania wszystkich dotychczasowych pozytywnych przejawów wzajemnego zbliżenia poprzez staranniejsze wzajemne poznanie, choćby przez studia nad działaniem Światowej Rady Kościołów ${ }^{24}$. Wtedy też dobitniej wyrażono pragnienie, aby przeszkody we wspólnej komunikacji pokonywać nie przez wysługiwanie się ,,autorytetami”, lecz poprzez wspólne badania teologiczne, prowadzące do rozumienia wiary w miłości i pokorze ${ }^{25}$.

\section{Ku tworzeniu jednego organizmu}

Jednym z najważniejszych osiągnięć w sferze przełamywania nieufności i uprzedzeń wśród podzielonych chrześcijan w ostatnim okresie jest znalezienie wspólnej motywacji do dialogu w zmienionych okolicznościach historycznych i doktrynalno-wyznaniowych. Na szczególne uznanie zasługuje tu, ze względu na pierwotną jedność, a następnie trwający wiekami bolesny rozdział, odrodzenie pragnienia wzajemnego okazywania szacunku i życzliwości Kościołów katolickiego i prawosławnego, a więc tych dwóch Kościołów, które w pewnym momencie postawiły sobie za cel prześciganie się we wzajemnej negacji, zamiast obustronnie czerpać z tego samego dziedzictwa wiary chrześcijańskiej, mającego dwie różne formy uzewnętrzniania. Ostatecznie jednak pozwolono dojść do głosu zmysłowi powrotu do pełnej wspólnoty, u którego podstaw leży pragnienie wzajemnego obdarowywania i ofiarowania. To, co się dokonało między Kościołem Rzymskokatolickim a prawosławnym w XX wieku, można śmiało nazwać obdarowaniem i ofiarą wspólnej przemiany.

Dzięki temu katolicyzm w znacznym stopniu przestał być postrzegany przez prawosławnych wyłącznie jako podmiot mający pretensje do przypisywania sobie powszechności chrześcijańskiej, z kolei katolicy przestali traktować prawosławie jedynie jako anachroniczną i skostniałą religię chrześcijańskiego Wschodu. Decydującym czynnikiem w zmianie ogólnego nastawienia i atmosfery we wzajemnych stosunkach było oficjalne zniesienie anatemy z 1054 roku równocześnie w Rzymie i Konstantynopolu w 1965 roku. Ta decyzja stała się naturalnym początkiem wspólnego odchodzenia od fałszywych stereotypów i stronniczego traktowania drugiej strony. Następnie prawdziwym potwierdzeniem realizacji nowej formuły zbliżenia między obydwoma Kościołami było podjęcie się przez papieża Pawła VI oraz patriarchę Demetriosa I w 10. rocznicę zniesie-

\footnotetext{
${ }^{24}$ Por. M. Schoof, Przełom w teologii katolickiej, thum. H. Bortnowska, Kraków 1972, s. 186-189.

${ }^{25}$ L. Górka, S.C. Napiórkowski, Kościoty czy Kościót, s. 104.
} 
nia ekskomunik (1975) ważnej misji utworzenia dwóch równoległych komisji, katolickiej i ogólnoprawosławnej, celem zainicjowania dialogu teologicznego. W wyniku intensywnych działań obu stron w roku 1979 za sprawą Jana Pawła II i Demetriosa I doszło ostatecznie do powołania Międzynarodowej Komisji Mieszanej do dialogu teologicznego między Kościołem katolickim a Kościołem prawosławnym, która to już w roku następnym rozpoczęła działalność na polu doktrynalnym.

Wydarzenie to uchodzi za jedno z najdonioślejszych w XX-wiecznym ruchu ekumenicznym, a jednocześnie wiązane są $\mathrm{z}$ nim ogromne nadzieje $\mathrm{w}$ stosunku do całego współczesnego procesu ekumenicznego ${ }^{26}$. Dzisiaj nie bez powodów mówi się o tym, że od trwałych efektów dialogu katolicko-prawosławnego zależeć będzie $\mathrm{w}$ istotnej mierze postęp zjednoczeniowy wewnątrz chrześcijaństwa. Nie ulega wątpliwości, że te dwa Kościoły niosą szczególną odpowiedzialność za wspólną tradycję pierwszego tysiąclecia, a to z kolei musi się przekładać na żywe pojmowanie wrażliwości względem siebie oraz na wspólne świadectwo. Aktualny wzrost zainteresowania zbliżeniem między katolikami i prawosławnymi i troska o nie nie jest sprawą przypadku, lecz obie strony powoli dojrzewały do przekonania o bezsensie bycia poza jedną wspólnotą. Poza tym przepaść, która powstała między nimi, okazała się w pewnym momencie nie do zniesienia dla nich samych, a po części także dla innych wspólnot chrześcijańskich.

Dążność do odrzucenia dawnej obcości stała się więc czytelnym znakiem podjęcia próby odbudowy zaufania we wspólną przynależność do tego samego organizmu oraz odrzucenia tego wszystkiego, co przez długie wieki jedynie osłabiało obie strony i ubożyło ich sposób pełnienia misji względem wiernych i świata. Aktualnie coraz wyraźniej widać pozytywne skutki wzajemnych relacji katolików i prawosławnych. Dokonujące się wciąż zmiany w postawie i wzajemnej afirmacji pozwalają z optymizmem patrzeć na przyszłość obydwu Kościołów. Są one w stanie nie tylko nazywać się Kościołami siostrzanymi, ale ze wspólnych dążeń zjednoczeniowych wypływa wciąż jednoznaczne przesłanie o kontynuacji i rozwoju osiagnniętego dobra przynależności do $\operatorname{siebie}^{27}$. Żadna ze stron nie neguje zdobyczy w wymiarze nowego spojrzenia na siebie, choć jednocześnie każda z nich ma świadomość, jak wiele trudności jeszcze przed nimi w pokonywaniu dawnego schematu myślenia i traktowania siebie nawzajem.

Zapoczątkowany dialog ma na celu zintensyfikowanie dążenia stron do osiagnięcia pełnej jedności wiary, lecz urzeczywistnianej według reguł zgodnych $\mathrm{z}$ własną tradycją. Dlatego w poszukiwaniu metody zbliżenia nie może być mowy o pozornym kompromisie czy próbie teologicznego konformizmu, gdyż to zaprzeczałoby idei głównej. Przecież do jedności nie można zmierzać uproszczoną

${ }^{26}$ W. Hryniewicz, Perspektywy dialogu katolicko-prawosławnego, „Biuletyn Ekumeniczny” 9 (1980), nr 3, s. 59-60.

${ }^{27}$ Tenże, Kościót jest jeden, Kraków 2004, s. 310-312. 
czy tym bardziej fałszywą drogą, choćby poprzez zacieranie różnorodności, odmienności i wielości. $Z$ tego też powodu od początku dialogu katolicko-prawosławnego wyjątkową rolę do odegrania ma wspomniana wspólna komisja teologiczna, której zadaniem jest troska o to, by nadrzędną wartością zjednoczenia była wiara ${ }^{28}$. Uzgodnienia teologiczne mają być temu podporządkowane, gdyż z natury swej mają one służyć systematyzowaniu i pogłębianiu refleksji nad treścią wiary. Natomiast nadmierna chęć wymiany stanowisk i obrony własnego punktu widzenia w dziedzinie doktrynalnej powinna ustępować zawsze miejsca wspólnemu dobru, jakim ma być jedność w wierze. $\mathrm{Z}$ wielu powodów można mówić, że aktualnie tak się właśnie dzieje, zaś potwierdza ten fakt choćby przyjęcie już podczas pierwszego spotkania wspomnianej komisji za przedmiot dyskusji problemu „Misterium Kościoła i Eucharystii w świetle tajemnicy Trójcy Świętej”29.

\section{Odpowiedzialność za wspólnotę powszechną}

Zasadniczą przesłanką utrwalania procesu zjednoczeniowego między katolikami i prawosławnymi jest świadomość więzi wspólnotowej, określana w chrześcijaństwie jako zjednoczenie w wierze, nadziei i miłości, a w przypadku tych dwóch Kościołów, również jako zjednoczenie w sakramentach, wielości charyzmatów i form posługiwania. Wszakże prawdziwe poczucie tożsamości obu tradycji eklezjalnych wiąże się nieustannie z przyznaniem nadrzędnej roli Duchowi Świętemu. On bowiem jest głównym sprawcą scalenia wszystkiego w jedność i nadania różnorodności charakteru dopełniającego. Duch powoduje, że wspólnoty lokalne wraz ze swoimi biskupami mogą być kontynuacją rzeczywistej wspólnoty apostolskiej. Natomiast skoro jeden jedyny Kościół realizuje się w Kościele lokalnym, to jego pasterz razem ze swoją owczarnią nie może pozostać obojętny na los Kościoła powszechnego, lecz wspólnie ponoszą zań odpowiedzialność, wcale nie mniejszą niż za swoje zgromadzenie lokalne. $Z$ tego tytułu pomiędzy wspólnotą lokalną a wspólnotą powszechną zawiązuje się szczególna relacyjność, której niezmiennym wyrazem współdziałania jest troska o jedność całego Kościoła na ziemi ${ }^{30}$. Tutaj jedność i wielość są tak dalece związane ze soba, że jedna nie może istnieć w oderwaniu od drugiej.

W dzisiejszym dialogu katolicko-prawosławnym na nowo może być postawiona kwestia jedności i wielości w kontekście przyszłym, czego jeszcze w nie-

${ }^{28}$ H.M. Biedermann, Orthodoxe und Katholische Kirche heute. Etappen des Gesprächs in den letzten 20 Jahren, „Catholica“ 33 (1979), s. 9-29.

${ }^{29}$ Wspólny dokument na temat Misterium Kościoła i Eucharystii w świetle Trójcy Świętej powstał w Monachium (30 VI-6 VII) 1982 roku.

${ }^{30} \mathrm{~J}$. Moskałyk, Lokalna wspólnota eklezjalna jako miejsce przemiany dynamicznej osoby wedtug Mikołaja Afanasjewa, w: Ja - wspólnota. Perspektywa teologii fundamentalnej, red. E. Kotkowska, J. Moskałyk, Poznań 2009, s. 81-96. 
dalekiej przeszłości nie potrafiono uczynić. Znaczy to, że teraz strony zdecydowały się podążać drogą otwartej dyskusji, przy jednoznacznym pragnieniu ostatecznego konsensusu. Ten wspólnie ustalony program działania nie jest w żadnym wypadku przymusowym wyborem, na który musiano się bezwarunkowo zgodzić. To zupełnie dobrowolne przedsięwzięcie, będące efektem połączenia siły woli, rozsądku i wewnętrznego pragnienia obu stron. Dlatego obecna wspólna wędrówka ku pełnemu zjednoczeniu nie może się odbywać w atmosferze „zapomnianej przeszłości", tak jakby historia dziś nas nie dotyczyła. Na przeszłość trzeba jednak spojrzeć z innej perspektywy, co obie strony dialogu uchroni przed pokusą omijania trudnych problemów obciążających stosunki między obydwoma Kościołami. Tych spornych kwestii jest tyle, że nie da się uniknąć dyskusji na ich temat. Jednocześnie nasuwa się pytanie, czy kiedykolwiek wszystkie moga być rozwiązane w sposób zadowalający dwie strony.

Między innymi właśnie dlatego niektóre środowiska greckie (głównie zakonne) w roku 1980 bardzo gwałtownie zaprotestowały przeciwko dialogowi katolicko-prawosławnemu, ponieważ nie widziały w nim szansy na zniesienie różnic z przeszłości między dwoma Kościołami ${ }^{31}$. W ich pojęciu złożona na zakończenie wizyty w Stambule w 1979 roku propozycja Jana Pawła II „oczyszczenia wspólnej pamięci”, to taktyka Rzymu nastawiona na wciagnnięcie prawosławia w niebezpieczną pułapkę przyszłego pojednania.

Jednakże incydent ten nie miał znaczącego wpływu na dalszy los dialogu katolicko-prawosławnego, gdyż strony postanowiły, że nie można zejść z wcześniej obranej drogi prawdziwego zbliżenia. Jest oczywiste, że rozpoczęciu dialogu towarzyszyła zarówno wielka nadzieja i ufność, jak też niepewność i nieprzewidywalność, bo przecież chodziło tu nie tylko o wspólne dobro, mające się wyrazić w pełnej jedności Kościołów oraz ukazaniu ich uczestnictwa w trwałej powszechności, ale ponadto o zachowanie swej tożsamości. Największe niepokoje, które wciąż dają znać o sobie, towarzyszyły właśnie kwestii zachowania odrębnej tożsamości. Rzecz dotyczy głównie strony prawosławnej oraz jej wewnętrznego zróżnicowania w podejściu do kwestii ostatecznego celu dialogu doktrynalnego i kontynuacji swej historyczno-tradycyjnej niezależności. Głównym czynnikiem niepokoju wydaje się tu wciąż problem miejsca i roli biskupa Rzymu w Kościele, w tym zasada prymatu i nieomylności, racjonalność typowo katolickich dogmatów oraz zagadnienie wschodnich Kościołów katolickich (tzw. unickich).

Niemniej jednak u podstaw optymizmu w dialogu katolicko-prawosławnym niezmiennie znajduje się czerpanie obydwu Kościołów z tej samej tradycji chrze-

\footnotetext{
${ }^{31}$ Czołową rolę w proteście wobec dialogu z katolicyzmem odegrały monastery z Athosu, które w podjęciu dialogu z katolikami upatrywały niebezpieczeństwo „duchowego samobójstwa prawosławia”. Por. „Service Orthodoxe de Presse et d'Information” (dalej SOP) 1980, nr 49, s. 4; W. Hryniewicz, Kościoły siostrzane. Dialog katolicko-prawosławny (1980-1991), Warszawa 1993, s. 83.
} 
ścijańskiej, odwoływanie się do dawnych uzgodnień soborów powszechnych jako wspólnego dziedzictwa nauki i wiary, oparcie na wspólnym źródle kultu liturgicznego oraz wzajemne uznawanie owoców zbawczych wypływających z działania religijnego. W końcu także świadomość niepodzielonej przeszłości pozostaje wciąż żywym wyzwaniem do przyszłego zjednoczenia chrześcijan w kontekście odpowiedzialności za swoją misję zbawczą.

\section{3. Świadectwo dialogu}

W ostatnim okresie autentyczna otwartość Kościoła katolickiego ma służyć przede wszystkim wzmożeniu aktywności ekumenicznej we wszystkich dziedzinach życia eklezjalnego, a jednocześnie inicjowaniu spotkań katolików z innymi wspólnotami chrześcijańskimi, co ma prowadzić do głębszego wzajemnego poznania oraz wypracowania strategii współpracy na gruncie zjednoczeniowym. Dzięki konsekwentnemu angażowaniu się w dzieło ekumeniczne w okresie posoborowym udało się podjąć dialog teologiczny ze wszystkimi znaczącymi Kościołami i wspólnotami kościelnymi. Spośród wielu inicjatyw dialogicznych na szczególną uwagę zasługuje m.in. wspominany proces zbliżenia z Kościołem prawosławnym, a ponadto Kościołem koptyjskim, Światową Radą Kościołów, Wspólnotą Anglikańską, Światową Federacją Luterańską, Światowym Związkiem Reformowanym, Światową Radą Metodystyczną, Kościołem Uczniów Chrystusa, Kościołem Pentekostalnym i Światowym Związkiem Baptystów ${ }^{32}$.

Warto zauważyć, że zasadnicza zmiana w nawiązywaniu relacji partnerskich zaczęła się już od Soboru, a dokładnie mówiąc, od zaproszenia na obrady plenarne $\mathrm{w}$ roli obserwatorów przedstawicieli Kościołów niekatolickich. Był to niewątpliwie akt bezprecedensowy, który zaświadczał o rozpoczęciu nowego rozdziału w stosunkach katolików z innymi wspólnotami chrześcijańskimi. Z cała pewnością można również powiedzieć, że nie chodziło tu o gest obliczony jedynie na poprawę dotychczasowego wizerunku katolików ani o jednorazowy epizod. Rzeczywistym potwierdzeniem szczerości intencji wobec obserwatorów było obdarzenie ich pełnym zaufaniem i możliwością uczestnictwa w nadzwyczajnym zebraniu Kościoła katolickiego. Przedstawiciele wyznań niekatolickich zostali włączeni w tworzenie nowego związku relacyjnego między poszczególnymi wspólnotami na płaszczyźnie soborowej. W tej sytuacji ich obecność w sali soborowej, jak zauważył Yves Congar, miała także wielki wpływ na atmosferę i ekumeniczną wymowę debat soborowych ${ }^{33}$. Dobitnym przykładem jest tu przyjmowanie uwag i spostrzeżeń obserwatorów przy tworzeniu projektów dokumen-

\footnotetext{
${ }^{32}$ Por. S.C. Napiórkowski, S. Koza, P. Jaskóła, Na drogach do jedności, Lublin 1983, s. $22-$ -57, także: L. Górka, S.C. Napiórkowski, Kościoły czy Kościót, s. 67.

${ }^{33}$ Y. Congar, Die Rolle der „Beobachter” in der Entwicklung der Ökumene, w: Möglichkeiten und Grenzen heute, Hsg. K. Fröhlich, Tübingen 1982, s. 50-62.
} 
tów soborowych. Ostatecznie obserwatorzy, mimo że mieli ograniczony wpływ na końcową wersję treści dokumentów, pełnili istotną misję doradczą oraz stali się świadkami całkiem nowego wymiaru dialogu.

Już wtedy położono podwaliny pod kontynuację ruchu na rzecz coraz bardziej aktywnej współobecności innych chrześcijan i współdziałania z nimi, a jednocześnie uczenie się wspólnego bycia na miarę aktualnych potrzeb i wymogów ludzi wiary oraz wzajemnego ubogacania się wartościami duchowymi bliskimi każdej autonomicznej jednostce. $Z$ tego to między innymi powodu zupełnie nową rolę zaczął odgrywać postulat protestantów oddania należytego miejsca chrystocentryzmowi w ekumenizmie i w ogóle w teologii. Nawiązanie do tego znajdujemy także w drugiej części Dyrektorium ekumenicznego z 1970 roku w słowach „Ekumenizm powinien wywierać wpływ na każdą naukę teologiczną, jako konieczny wymiar każdej z nich, pomagając do szerszego ukazania pełności Chrystusa" 34 .

Podobną koncepcję rozwoju świadectwa dialogu chrześcijańskiego głosi Światowa Rada Kościołów, która składa się z Kościołów uznających Jezusa Chrystusa za Boga i Zbawiciela ${ }^{35}$. Jest tu wyraźne wskazanie na potrzebę powrotu do Chrystusa jako zasady, która może gwarantować chrześcijanom odnalezienie prawdziwego sensu jedności. Nie istnieje inna droga, która mogłaby prowadzić do jedności. Stąd ważne jest pokonanie w sobie ukrytej żądzy górowania nad drugim Kościołem albo zagarnięcia go w swoje posiadanie. Jest to szczególnie istotne w okresie, jak się wydaje, ostatecznego odstapienia od niedobrej tendencji wzajemnej alienacji chrześcijan. Jeśli w życiu chrześcijan pierwszym i najważniejszym punktem odniesienia będzie Chrystus, to mimo istniejących między nimi różnic będą stopniowo zbliżać się do Niego i do samych siebie, by na koniec osiagnąć pełną jedność ${ }^{36}$.

Dzisiaj, choć wciąż jeszcze widać wahanie i niedowierzanie, mamy do czynienia $\mathrm{z}$ zupełnie innym nastawieniem i preferencjami dotyczącymi wykorzystywania podstawy chrystologicznej w doktrynie ekumenicznej. Przykładem tego jest m.in. Raport z Malty ${ }^{37}$, w którym teologowie katoliccy i luterańscy podkreślili daleko idącą zbieżność co do istoty nauki o usprawiedliwieniu, ze względu na wspólne zainteresowanie chrystologiczne. „Jedność wyrasta z miłości Bożej w Jezusie Chrystusie, który wiążąc ze sobą poszczególne Kościoły, jednoczy je

\footnotetext{
${ }^{34}$ Dyrektorium ekumeniczne II, rozdz. II, 2.

${ }^{35}$ Por. Die erste Vollversammlung des Ökumenischen Rates der Kirchen in Amsterdam vom 22. August bis 4. September 1948, Hsg. W.A. Vissert Hooft, Zürich 1948, s. 168-169.

${ }^{36}$ Por. O. Cullmman, O. Karrer, Einheit in Christus. Evangelische und katholische Bekenntnisse, Zürich - Köln 1962, s. 24-27.

${ }^{37}$ S.C. Napiórkowski, Ewangelia a Kościól, czyli tzw. Raport z Malty, w: tenże, Wszyscy pod jednym Chrystusem, Lublin 1985, s. 117-139.
} 
przez to między sobą"38. Jest to wskazanie, na którym musi być nieustannie skoncentrowana myśl i dążenie wszystkich chrześcijan.

\section{Uznanie potrzeby akceptacji}

W ostatnich kilku dziesięcioleciach chrześcijaństwo, w tym także katolicyzm, przeszło istotną drogę przemiany i odeszło od dawnej postawy nieufności względem religii niechrześcijańskich. Powodów tej wyraźnej zmiany należy doszukiwać się m.in. w takich czynnikach, jak: pragnienie głębszego samowyrażenia poprzez bardziej otwarte relacje $\mathrm{z}$ wartościami religii niechrześcijańskich, nowa konfrontacja między religią a ateizmem oraz ostateczne opowiedzenie się za możliwym pluralizmem zbawczym. Choć każda religia w odmienny sposób pojmuje komunikację rzeczywistości doczesnej z ponaddoczesną i jest w pewnym sensie nieporównywalna $\mathrm{z}$ innymi, to oczywiste jest to, że właściwa religia wiąże się z religią objawioną historycznie i do niej należą judaizm oraz chrześcijaństwo $^{39}$. Jeśli chodzi o religie niechrześcijańskie, to również one ze względu na swój udział w przekazie światu doczesnemu rzeczywistości boskiej mogą stanowić przestrzeń jej wielbienia i jednocześnie prowadzić człowieka ku odkupieniu w Bogu. W tym sensie są one włączone w odpowiedzialność za objawienie powszechne i powszechną historię zbawienia. Do objawienia powszechnego należą naturalne prawdy religijne, które odkrywają istnienie Boga i wskazują na zasady etyczne.

Dzisiaj chrześcijaństwo, także ze względu na swoje długotrwałe wyobcowanie, chyba bardziej niż kiedykolwiek wcześniej gotowe jest uznać liczne elementy prawdy w religiach niechrześcijańskich, a dzięki temu głębiej doświadczać daru i posłannictwa chrześcijańskiego, nie ustając w rozwijaniu i umacnianiu swoich więzi z Chrystusem. Widać też ponadto, że zaczęło uznawać, że inne religie dążą do pełnej dojrzałości duchowej.

\section{Otwarcie na dialog międzyreligijny}

Chrześcijaństwo od dłuższego już czasu przygotowywało odpowiedni grunt $\mathrm{w}$ celu zdynamizowania relacji $\mathrm{z}$ innymi religiami, mając przy tym na uwadze zawsze zarówno dobro własne, jak i poszanowanie całkowitej autonomii strony drugiej. Proces ten dojrzewał powoli, ale konsekwentnie, dzięki czemu - zwłaszcza po stronie katolickiej - otrzymał bazę źródłową w dokumentach Soboru Watykańskiego II w Dekrecie o ekumenizmie (rozdz. II). Tutaj można przyjąć, że w katolicyzmie, a po części może także dzięki niemu, w całej myśli chrześci-

\footnotetext{
${ }^{38}$ Die erste Vollversammlung des Ökumenischen Rates, s. 168.

${ }^{39}$ Por. R.W. Smith, Religion of the Semites, London 2002, s. 32-36.
} 
jańskiej dochodzi ostatnio do odrodzenia żywej intuicji religijnej opartej na dialektyce, czyli poczuciu pełnej tożsamości i komunii z innymi ${ }^{40}$. Co to znaczy w praktyce? Przede wszystkim coraz powszechniejsza jest świadomość znaczenia czynnika religijnego, który dostarcza odpowiednią wiedzę i ułatwia refleksję o świecie, człowieku, wartościach i pierwiastku nieskończoności. Właściwe upodmiotowienie w religii lub wyznaniu wyzwala od wszelkiej wrogości wobec innych oraz chroni przed fałszywą tendencją do konfesyjnej wyłączności. Taka bowiem najbardziej zagraża rozdrobnionym wspólnotom religijnym, które niejako symptomatycznie starają się bronić przed większymi i bardziej zorganizowanymi wyznaniami.

Duże wspólnoty, na przykład chrześcijańskie, które mają określony porządek prawno-strukturalny, są więc mniej narażone na lęk i niepewność o zachowanie swojej tożsamości. Im też jest łatwiej występować z inicjatywą otwartej komunikacji z innymi religiami. Z kolei doświadczenie historycznego podziału, który w chrześcijaństwie najczęściej był skutkiem nietolerancji wobec drugiego Kościoła czy wspólnoty oraz dążenia do całkowitego panowania, skłania do coraz głębszej rewizji dawnej postawy zdystansowania i walki o własną dominację. W tym pełniejszym otwarciu się chrześcijan na inne religie, na przykład monoteistyczne, coraz większą rolę zaczyna odgrywać nowe podejście w myśleniu.

Na tę rzeczywistość w swoim czasie wskazał Gustav Siewerth (†1963), który uznał wzajemne tolerowanie się światopoglądów oraz wielkich poglądów religijnych za niezbędny kierunek wszechstronnego poznania rzeczy i zdarzeń objawiających Boga $^{41}$. Żadna religia ani tym bardziej jednostka ludzka nie jest w stanie poznać całego wymiaru istoty stworzonej i jej przeznaczenia czy także posiąść o niej absolutnej prawdy. Dlatego wciąż potrzebne jest tworzenie pewnej relacyjności o charakterze tolerancyjnym, gdzie odrębnie ukształtowane poglądy, między innymi na wolność człowieka, prawa społeczeństw i religijną autonomię, będą tworzyły system wzajemnego dopełnienia. W taki sposób tolerancja będzie przybierać formę bytowania współ-osobowego, współ-partnerskiego i osobowo-moralnego.

Dziś paradoksalnie można stwierdzić, że chrześcijaństwo pod wpływem dawnych ostrych sporów i polemik wewnętrznych stało się bardziej tolerancyjne względem własnego środowiska wiary a jego stosunek do innych społeczności religijnych nacechowany jest większą wrażliwością. Fundamentalne znaczenie miało tutaj nowe spojrzenie na kategorię jedności w myśleniu i działaniu chrześcijan. We współczesnym rozwoju relacji między chrześcijanami oraz chrześcijan z innymi religiami zasada jedności ma coraz głębsze uzasadnienie. Poprzez powszechne dowartościowanie jedności staje się także możliwe dostrzeżenie

\footnotetext{
${ }^{40}$ Por. C.S. Bartnik, Istota chrześcijaństwa, Lublin 2004, s. 125.

${ }^{41}$ Por. G. Siewerth, Sein und Wahrheit, Düsseldorf 1975, s. 73-75.
} 
bogactwa wielości w zróżnicowanych doktrynach, systemach i praktykach. To z kolei wzywa do właściwego równoważenia funkcji jedności w odniesieniu do kategorii wielości i różnorodności, tak by nie dochodziło do dewaluacji tej pierwszej i najważniejszej zasady, co aktualnie niejednokrotnie jawi się jako zagrożenie ze względu na gwałtowne przesuwanie środka ciężkości na wielość kosztem prymatu jedności.

Dopuszczalna wielość wizji doktrynalnych, systemów oraz hermeneutyk choćby chrześcijańskich, postulowana niegdyś m.in. przez Karla Rahnera $(\dagger 1984)^{42}$, nie oznacza bynajmniej dowolności ich łączenia w całość, co miałoby przyspieszyć zjednoczenie. Absurdalne bowiem byłoby „dopasowywanie” wielu, niekiedy zasadniczo sprzecznych rozwiązań w celu utworzenia jednego wyznania, wspólnoty czy Kościoła. Najpierw trzeba dążyć do całkowitej akceptacji odrębnych koncepcji i swobodnego ich rozwoju, a dopiero później do wypracowania odpowiedniej atmosfery do rzetelnej weryfikacji podczas spotkań dwu- lub wielostronnych. Wydaje się, że obecnie jesteśmy na właściwej drodze do wiarygodnego uznawania odrębności świadomościowej i doktrynalnej innych religii oraz obiektywizowania atmosfery, co ma umożliwić lepsze wzajemne poznanie. $\mathrm{W}$ tym niewątpliwie należy dostrzegać istotną rolę przemian w relacjach wewnętrznych chrześcijan.

\section{Zasada realizacji religijnej}

Jest normalne, że o postawie religijnej decydują takie czynniki, jak: nastawienie wolitywne, emocjonalne, dążeniowe, kreatywne itd. Elementy te w różnych religiach, a także różnych narodach, kulturach i obrzędach, są w odmienny sposób eksponowane, co stanowi o ich specyfice. O ile treści religijne łączą się z określonym otoczeniem i dynamiką działania, o tyle ich prawdziwą podbudową muszą być typowe zachowania, przekonania i poglądy ${ }^{43}$. Z tym wiąże się także specyfika nastawienia do ludzi i społeczności inaczej wierzących, a dokładnie mówiąc, afirmacja kierunku realizacji religijnej samodzielnych środowisk wyznaniowych. Mając to na uwadze, trzeba pamiętać, że otworzyć się na inne zbiorowości religijne można dzięki uniwersalizacji prawdy. Dopiero wówczas troska o własną tożsamość zostaje uwolniona od determinacji siły konfesyjności. Oczywiście, znacznie łatwiej jest ustalić tego rodzaju tezę na podstawie analizy źródłowej zjawiska tożsamości w relacji do konfesyjności aniżeli w praktyce zapanować nad ich prawdziwym współodniesieniem, czego przykładem jest ekumenizm rozwijany głównie w wymiarze prakseologicznym.

${ }^{42}$ K. Rahner, Der Plurarismus in der Teologie und die Einheit des Bekenntnis in der Kirche, w: tenże, Schriften zur Theologie, Bd. 9, Einsiedel 1970, s. 11-28.

${ }^{43}$ Por. A. MacIntyre, Dziedzictwo cnoty. Studium z teorii moralności, thum. A. Chmielewski, Warszawa 1996, s. 356-362. 
Historyczne próby zbliżenia dają wystarczające powody do stwierdzenia, że fałszywie bądź naiwnie rozumiany ekumenizm jest bardziej szkodliwy od jego braku, ponieważ chęć bratania się z każdym za wszelką cenę może prowadzić do degradacji każdego wyznania. Dlatego pierwotne chrześcijaństwo z pewnością nie bez powodu mocno broniło się przed synkretyzmem i utratą własnej tożsamości. W kontekście dzisiejszych prób zjednoczeniowych i zbliżeniowych wewnątrz społeczności wierzących nie można lekceważyć tego przykładu zwłaszcza dlatego, by nie doprowadzić do utraty tożsamości wyznaniowej chrześcijan - katolików, prawosławnych, protestantów itd. - a wyznawców pozostałych religii monoteistycznych oraz wyznań politeistycznych nie włączyć we współczesną nieokreśloną wspólnotę wyznaniową. Tym większe byłoby to zgorszenie, gdyby do tego przyczynić się miał ruch ekumeniczny.

Stąd, pragnąc obiektywnie spojrzeć na perspektywę dalszych działań unifikacyjnych i relacje między Kościołami, wspólnotami i religiami w świecie współczesnym, trzeba z nieudawaną szczerością wyznać, że ich prawdziwe porozumienie i współprzenikanie może się dokonywać dzięki pierwiastkowi duchowej dojrzałości i miłości. Naturalnym źródłem konstytutywnym staje się w tym względzie dawne dziedzictwo kultury duchowej i rozwinięta świadomość komunii ludzkiej. Tylko na nich można umacniać i udoskonalać skuteczne działania pojednawcze. Obecnie z tego natchnienia czerpie ruch ekumeniczny i powszechny program zbliżenia religijnego. Ciagle jednak jest mało żywej praxis, której i sami chrześcijanie niejednokrotnie nie potrafią docenić. Ona zaś połączona ze światłem rozumu może znosić wiele przeszkód i - co najważniejsze - chronić przed wynaturzeniem. Obecnie potrzeba właśnie takiego działania, które będzie od wewnątrz przemieniać jednostki i społeczeństwa wierzących, kształtując je na obraz prawdziwej wspólnoty, przejętej aktem stworzonej ekonomii Bożej.

$* * *$

Problem zjednoczenia chrześcijan oraz zbliżenia międzyreligijnego w swej istocie jest złożony i wieloaspektowy. Próba spojrzenia na tę kwestię ze strony doświadczenia alienacji dziejowej jest pragnieniem wyjaśnienia czegoś, co z zasady wyklucza możliwość pojednania. Zjawisko wyobcowania w stosunkach międzywyznaniowych bardzo często bywa pomijane, zaś jego konsekwencje są skrzętnie przemilczane. Tymczasem właściwa ocena wyobcowania we wzajemnych relacjach Kościołów czy religii powinna być zwykłym gestem odwagi i przejawem pragnienia doprowadzenia do zmiany obecnej sytuacji. Jednak przemiana owa jest nieosiagalna przy użyciu prostych środków ani tym bardziej nie dokona się na czyjeś żądanie. Potrzebna jest raczej długa droga katharsis oraz uznanie znaczenia utrzymywania dobrych relacji z innymi. Tego potrzebował i wciąż potrzebuje Kościół katolicki oraz całe chrześcijaństwo. Wspólnota chrze- 
ścijańska jest wezwana do prawdziwej postawy otwarcia, w tym otwarcia ekumenicznego, dzięki czemu ma pełnić szczególną misję w doczesnym świecie.

\section{The Experience of Historical-Religious Alienations and Modern Relationships within Christianity}

\section{Summary}

The problem of unity within the Christian and interreligious rapprochement is in its essence complex and multifaceted. The attempt to look at this issue through the experience of the alienation complex wishes to cast some light on the factors that in principle exclude the possibility of reconciliation. The phenomenon of alienation in interdenominational relations is very often overlooked, and its consequences are hastily hushed up. However, a proper assessment of the situation of alienation in mutual relations between churches or religions should be a simple gesture of courage and willingness to make a change. Yet, this is not simple, all the more so when done at someone else's request. It is still a long way to catharsis and a sense of fellowship with others, but this is what the Catholic Church and the entire Christianity needs. A genuine attitude of openness, ecumenical openness included, is what the Christian community is called to in order to perform its specific missions in the contemporary world.

\section{Keywords}

the Catholic Church, Christianity, alienation, dialogue, Christian mission

\section{Słowa kluczowe}

Kościół katolicki, chrześcijaństwo, wyobcowanie, dialog, misja chrześcijańska 